\title{
The Value of Seligman's Optimism in Disorder Novel as Teaching Materials of Indonesian Language in SMA
}

\author{
Munaris \\ Department of Language and Arts \\ Education \\ Lampung University \\ Lampung, Indonesia \\ munaris.1970@fkip.unila.ac.id \\ Rahmat Prayogi \\ Department of Language and Arts \\ Education \\ Lampung University \\ Lampung, Indonesia \\ rahmat.prayogi@fkip.unila.ac.id
}

\author{
Heru Prasetyo \\ Department of Language and Arts \\ Education \\ Lampung University \\ Lampung, Indonesia \\ Heru.prasetyo@fkip.unila.ac.id \\ Ryzal Perdana \\ Educational Science \\ Lampung University \\ Lampung, Indonesia \\ ryzalperdana2009@gmail.com
}

\author{
Ayu Setiyo Putri \\ Department of Language and Arts \\ Education \\ Lampung University \\ Lampung, Indonesia \\ Ayu.setiyoputri@fkip.unila.ac.id
}

\begin{abstract}
This study aims to describe and explain the value of Sellingman's optimism contained in the novel Disorder by Akmal Nasery Basral so that it can be used as Indonesian language teaching material in high school. The method used in this study is a qualitative descriptive method. The data in this study are in the form of words, phrases, clauses, sentences, and paragraphs that contain information about the value of Sellingman's optimism in the novel. The structural approach is used as a scalpel because it is used to describe the findings in the novel structure. The validity of the data used is investigator triangulation. Data analysis resulted in finding the presence of Sellingman's optimism value in Novel Disorder in the novel, namely permanence, pervasiveness, and personalization.
\end{abstract}

Keywords-Sellingman optimism, structuralism, novel disorder

\section{INTRODUCTION}

The hard-hit given by Corona Virus Disease-2019 (Covid-19) targets almost all lines of life. Political, social, economic, and cultural cannot be separated from the impact of this pandemic. The world of literature and writing is no exception, the presence of Covid-19 has also had positive and negative impacts for some writers in Indonesia. The disorder may be a positive impact on a pandemic. Because he is one of several literary works born in this era and tries to tell the story of what people experienced during the pandemic.

Like any other novel. This novel by Akmal Nasery Basral is mimesis or imitation of the reality that exists in life. Its creation is born from events that occur in the surrounding environment. It is as if this work was born as a recorder, document, or historical archive which later generations can trace about the pandemics that have happened and been experienced by the community.

The close relationship of social, cultural, and political realities that occur in society with a literary work has existed for a long time. The assumption is that literature is a mirror [1] in an article numbered in 1953 entitled The Mirror and The Lamp stated that literature is not only a reflection of society but also a psychological mirror (personality). It is called a mirror because it has the property of reflecting an image, just like what happens in literary works which are a reflection of social reality. Although it is often said to be imaginative, literature sometimes unconsciously embeds data concerning social conditions and the period in which the story occurs. Incidentally, the novel Disorder packs a pandemic as a means of telling apocalyptic stories (related to destruction or apocalypse) and the attitudes of several characters through it.

This appears in the novel, through Permata Pertiwi and other characters presented. The description of this epidemiologist in the novel provides a complete picture that can inspire readers about the value of optimism. The resemblance to what is happening today is astonishing and worthy of a lesson for readers. 
[2] Describing individuals who have the nature of optimism that will be seen in certain aspects such as, (1) Permanent which is discussing how a person reacts to events that happen to him whether it will last long or temporarily, (2) Pervasiveness discusses how a person views failure and success that has occurred to him, whether he views universally or specifically, and (3) Personalization discusses how a person views failure and success due to internal and external factors. The aspects of Seligman's optimism value are straightforwardly raised by the author so that readers are amazed at the characters and characterizations of the novel Disorder when trying to find the mystery behind the pandemic events.

Research related to Seligman's optimism is not new. Like the research conducted by Nisa Nur Amalina entitled Martin Seligman's Value of Optimism in Voltaire's Roman Candide ou L'Optimism (An Overview of Positive Psychology) in 2015. This research finds the fact that aspects of optimism are found in the French literary work Candide ou $\mathrm{L}^{\mathrm{ee}}$ Optimism is: permanence, pervasiveness, and personalization of the characters Candide, doctor Pangloss, Miss Cunégonde, and the grandmother. However, pervasiveness was not found in the figure of Doctor Pangloss.

Through this study, it is hoped that an alternative reference for teaching materials will be presented following the demands of users. Novels with contemporary stories, authors with big names, and of course quality in terms of presentation. About how the optimism aspect is inserted in a novel by the author. So that in the end, the novel under study is worthy of being used as teaching material as an effort to meet the thirst of readers' knowledge of literary treasures as a whole. Both as teaching material or a proper reference in Indonesian language and literature lessons as well as for the wider community.

\section{LITERATURE REVIEW}

The creation of literary works is believed to be the embodiment of the author's journey and life journey. The inspiration obtained by the author when producing a literary work is generally based on the experiences that have been obtained from the realities of life that have been experienced in the surrounding community. Departing from this, generally, reality will be born into a literary work and presented with a different approach so that it can be enjoyed by a wide audience [3].

\section{A. Novel}

The novel entitled Disorder is a literary work that was born from mimesis that occurred at the end of 2019 and the beginning of 2020. The representation of the atmosphere of the Corona Virus Disease-2019 (Covid19) pandemic seemed to be presented to the reader for real. Permata Pertiwi's optimistic attitude as the main character, for example, seems to awaken readers to take a positive attitude in dealing with the pandemic. A situation that is also being experienced by the Indonesian people who are struggling with Covid-19. However, the true literary work is imagination. Although there are many similarities with reality because there is mimesis in it, several details in terms of characters, plot, and plot are purely fiction by the author.

In contrast to the types of literary works known in the community, the novel is a literary work that is quite complex. If poetry and drama have limits in terms of exposure. Novels have the freedom in telling stories to readers. So it's not surprising that novels can rarely be finished in one sitting. Novel descriptions are more complex. Details of characters, plots, and the like in the form of a long description are written in the hope that the reader can be involved in the world of the author's imagination.

This is explained by [4] which states that the novel is a literary work in the form of prose where the events in it are related to human life as experienced in everyday life, about joy and sorrow, love and hate, about character. and his soul, and so on. Meanwhile, according to [5] the novel is described as a work of fiction which in principle offers a world that contains an ideal but imaginary life model. The world is built through several intrinsic elements from the novel itself such as plot, characters, characterizations, setting, point of view, and others.

\section{B. Structuralism and Literary Psychology}

The complexity created by a literary work cannot be interpreted directly. The interweaving of literary elements will generally provide a separate understanding for the reader. Because literary works, as stated by [6] are works of art. Because it has its beauty value, works that are not beautiful are not considered literary works. This requires the right approach to analyze and interpret literary works. Literary structuralism as a literary approach emphasizes intrinsic elements as the building blocks of literary works. The presence of structural analysis makes the intrinsic meaning in a literary work can be explored more deeply and in detail. Structural analysis is known to have the aim of providing more detailed and strong information through structural analysis in the form of content with good meaning in a work.

\section{Seligman's Optimism}

To make it easier to identify the problem of optimism, it is necessary to have a deeper understanding of the aspects that exist in optimism [7]. Describing individuals who have the nature of optimism that will be seen in certain aspects such as, (1) permanence, which is an aspect of optimism that will discuss how a person responds to events that happen to him whether it will take place in the future. long term or temporary. For those who have an optimistic view, they will believe that negative events that happen to them are temporary, on the contrary for positive events 
that occur can be long or permanent, (2) pervasiveness is an aspect of optimism that discusses how a person views failure and success that has happened to him, whether it is universal or specific. Optimistic views believe that failure occurs because of something specific. On the other hand, success is caused by something universal, and (3) the last is personalization. This aspect of optimism discusses how to discuss how someone views failure and success that occurs due to internal or external factors. For people with an optimistic outlook, they believe that mistakes are from external factors, and success comes from internal factors.

\section{THE STUDY}

The research study used is qualitative research. According to [8] qualitative research is a type of research whose findings are not obtained through statistical procedures or other forms of calculation and this research has the aim of expressing holisticcontextual symptoms through collecting data from natural settings by utilizing the researcher himself as a key instrument. While [9] gives the meaning that qualitative is research that intends to understand the phenomenon of what is experienced by the research subject, for example, perceptual behavior, action, motivation, in a manner and by way of description in the form of words and language. In qualitative research, the researcher becomes the key instrument. The qualitative method is descriptive analysis with a study of the content analysis used by the author. Descriptive analysis research contains data excerpts to provide an overview of the presentation of the report. Psychological and structuralism approaches are used to dissect the optimistic attitude that appears in the novel through exposure in the form of words or phrases, or sentences in the novel Disorder by Akmal Nasery Basral.

The primary data source used in this research is the Novel Disorder by Akmal Nasery Basral totaling 496 pages published by Bentang Pustaka. Published in 2020, the research data are the characters and characterizations depicted in the novel that represent Seligman's optimism. The validity of the data in this study uses investigator triangulation. [10] State that data analysis in a qualitative study consists of three activities, including data reduction, data display, and concluding. The data obtained will be written in the form of a report based on the data obtained, which will then be reduced, and finally selected for presentation. The data is presented based on the main problem category, namely Seligman's optimism aspect.

\section{FINDINGS}

Disorder novel written by Akmal Nasery Basral is an interesting novel to be discussed in depth. Not only because of the controversy and courage of the writer who tried to present an apocalyptic story (a story relating to destruction or doomsday). However, Akmal is unexpectedly able to bring readers into the story he wrote about a pandemic that has hit the world again in fiction. Interestingly, the arrival of the pandemic was accompanied by a spice of intrigue, romance, and conspiracies that gave birth to optimism in the characters who appeared in the novel.

Novel Disorder itself tries to take a setting that is very close to the Covid 19 pandemic which began in 2020. Until now, the pandemic is still haunting the world, marked by the high number of deaths, causing economic, political, and social chaos both at the local and international levels. If the Coronavirus has a special long name, namely Severe Acute Syndrome Coronavirus Sars 2 (SARS-CoV2). In the novel Disorder, the virus reappeared and mutated in 2026 with the same panic, namely the Swine Origin Influenza Virus (SOIV-26) pandemic which was spread from the G4 EA HiN1 virus. If Covid 19 originated from a bat virus in Wuhan, Disorder seems not to be outdone by bringing out SOIV-26 from the Yaji Mountain pig farm. Both places are in the People's Republic of China.

Meanwhile, the story of this novel revolves around three important figures, namely Dr. Permata Pertiwi, or fondly called Ata, an epidemiologist from the Faculty of Public Health (FKM) Universitas Indonesia (UI), a beautiful kite in her 30s. The next figure is Prof. Dr. Tobias Shochet, Professor of Epidemiology from the University of Lyon, France, who is also the supervisor of Dr. Ata's dissertation at the University. The last character is Alex Lauw, a Chinese-born who had dated Ata during high school.

It was also mentioned that a confidential Mondial organization took part, namely The Global Order of Interconfessionalism for A Better World or abbreviated as TGO. According to the story in the novel, TGO has representatives around the world who are also secretive. Headquartered in London, England with the highest leadership being a Super Grand Master and assisted by 12 people with Grand Master titles whose membership comes from all over the world. The 12 Grand Masters are divided into two, six are representatives of the world's major religions and six others are drawn from university scientists and intellectuals, all of whom have doctoral degrees.

TGO intends to create a new world order that is more balanced and for the welfare of mankind as a whole. The current situation is felt to be unfair and oppressive. Rich countries are getting richer while poor countries are getting poorer. For this reason, it is necessary to fight in various ways, including by activating and spreading biological weapons such as bacteria or viruses.

\section{DISCUSSION}

\section{A. Fact Analysis of Disorder Novels}

The characters, plot, and setting are the facts of the story. These elements serve as a record of the 
imaginative events of a story. If summarized into one, all these elements are called factual structure or factual level of the story. The factual structure is not separate from a story. The factual structure is one aspect of the story. A factual structure is a story that is highlighted from one point of view.

Based on the chain of events contained in Novel Disorder, the main plot is formed according to the following stages: exposure to stimulation is the initial event of the novel plot; Seriousness, conflict, complexity, up to the climax are part of the event which is filled with various tensions and conflicts. Dissolution to completion is the ending event in the story.

The plot used by the author is a straight line. One type of plot that explains events chronologically, the first event is followed by other events that are sequentially in chronological order. Coherently the story starts from the initial stage (situation, introduction, conflict emergence), middle (conflict increases, climax), and the end (settlement).

The researcher concludes that the main character in the novel Disorder is Permata Pertiwi. It can be seen that the intensity of Permata Pertiwi's involvement with other figures dominates. When referring to the theory, where the main character is the character whose story is prioritized in the novel in question, the most widely narrated, both as the perpetrator of the incident and who is subject to the incident, the intensity of Permata Pertiwi's involvement in every chain of events makes her the main character in the novel Disorder.

\section{B. Aspects of Seligman's Optimism in the Novel Disorder by Akmal Nasery Basral}

The novel Disorder focuses on Permata Pertiwi as the main character, presenting a variety of positive messages that can be captured by the reader. His desire to solve the problem of the pandemic until it reached Harbin, China gave readers its description of the meaning of optimism of a man who was successfully packaged by the author in doctor Ata.

To make it easier to identify the problem of optimism that is present in the text, it is necessary to have a deeper understanding of the aspects that exist in optimism. [2] Describing individuals who have optimism that will be seen in certain aspects such as, (1) permanence, (2) pervasiveness, and (3) personalization. All three are present in the novel Disorder in the following discussion.

This aspect of optimism is reflected in the conversation between Shmuel and Professor Shochet who discussed the death of the French pig farm consultant Saint-Cyr-Sur-Menthon. Between his surprise in explaining, Shmuel tried to ask questions that seemed to make sure that the death had nothing to do with a new pandemic. Excerpts in the novel are as follows.
"The victim just returned from China two weeks ago, I'm not too sure the name of the place. Yazi Mountains? Yuzi? Yozi? That's more or less like that."

"Ah, of course," Professor Shochet snorted. "He must have just visited the Hog Hotel in the Yaji Mountains."

"Professor knows that place?" Shmuel sounded amazed.

"The Hog Hotel to hog farmers is like Las Vegas to gamblers. It was a modern ranch with tall, ten-story buildings. One floor is occupied by a thousand pigs. The transfer of pigs between floors using an elevator. The Chinese are the biggest consumers of pork."

"Is...," Chmuel's voice sounded doubtful, "it's what I imagined it to be, Prof?" (Disorder, 2021:24)

This aspect of optimism is also present in the novel when Ata talks when discussing the emergence of a mysterious virus case in Atambua. At that time, Ata explicitly stated that an autopsy on the farmer's corpse should be carried out to see what threats were being faced. Excerpts from this permanent aspect are as follows.

"One quick excuse?" He took a breath. "If we are late, thousands of people will die here. The infection would spread rapidly and kill thousands more nationwide. Maybe penetrate one soul. Much worse than Covid-19 in 2020."

"Holly Mary. Seriously?" Professor Mboi sounded tense. (Disorder, 2021:36)

Permanence, which is an aspect of optimism, focuses on how one's attitude towards an event that is faced, whether it lasts long or temporarily, is also shown when Professor Shochet gives a press statement. He told reporters that despite how advanced medical technology is in the world, this new war presents a more sophisticated and stubborn variant of the virus than its ancestors. So that, in the end, will make the world order change again.

"Mankind's war against disease will never end. No matter how advanced our medical technology is, there is always an opening for viruses, bacteria, and other microbes to conquer us," said Professor Shochet.

"...However, at this time we will enter the arena of the latest battle against the most advanced variant viruses and are more stubborn than their ancestors. What is happening now is showing those early symptoms."

"Professor Shochet, are we still not ready in 2026 to face the worst of the pandemic?" chases the interviewer.

"We're still not ready. Never ready." (Disorder, 2021:59) 
The next excerpt about the aspect of permanence is when Ata spoke with Professor Mboi at the University of Indonesia. Professor Mboi, who has seen the direction of the new pandemic, advised Ata to focus on his territory while Professor Mboi was in Atamabua, Timor, and NTT.

"Let me take care of Atambua, Timor, and NTT, Doctor Ata takes care of other areas. If the Doctor's intuition about this epidemic is correct, a very serious problem is threatening us."

Or relieved. "Thank you for the support Professor. Hopefully we're not too late." (Disorder, 2021:76)

In the novel Disorder, the data related to the perception of failure and success appear as follows.

"What other indications, Doc? Besides the deaths of the three breeders I mean."

"I don't have one yet. Just intuition. This is like an axiom in the world of epidemiology. The next pandemic is coming, we just don't know when exactly."

"Scientists' intuition is the most sensitive cue compared to a pile of data that officials have, but they don't understand the substance so they often take wrong policies," said Professor Mboi.

"That's why I don't want Timor Island and its surroundings to become a mass grave."

The last aspect of optimism discusses how a person views failure and success due to internal and external factors called personalization. Personalization is the easiest dimension to understand. Personalization relates to sources of causes, internal and external. Optimistic people view pressing problems from the side of environmental problems (external) and view pleasant events as coming from within (internal). On the other hand, pessimistic people view pressing problems as coming from within (internal) and considerable success as a result of situations outside of themselves. (external).

This data has been available since the beginning of the novel. At the beginning of the introduction of Ata, or Permata Pertiwi which is the main character, the author explains Ata's habit of walking fast which was inspired by his lecturer.

He walked along the mechanical trunk in a hurry, a walking habit that had been formed since he was a student of the Faculty of Medical Sciences. The reason is simple. A lecturer in Basic Biomedical Scienceswhich he studied in the first semester - said in his first lecture, "One second for a doctor can save a patient's life or die in great suffering. People who like to procrastinate, no matter how smart their brains are, will not be suitable to be doctors whose lives are always in a race against time." From that moment on the lecturer's words tied the gastrocnemius and sleus muscles attached to the Achilles tendon at his ankle which connected to the heel.
Another data emerged when Ata was praised by Professor Shochet, who was also his supervisor during his first lecture. Professor Shochet's commendation states that Ata is a proud alumnus and has a brilliant career.

"What if I leave early next week, Prof?"

"Good. I will send a cover letter for visa processing to the French Embassy in Jakarta as my invitation from the University of Lyon. You are a proud graduate."

"Thank you, Professor Shochet," said Ata, trying his best to keep his nostrils from expanding because the Professor was not the type of person who likes to give compliments. "I was fortunate to be directly mentored by the Professor."

"Ah, forget the pleasantries. You're not the only one I'm helping. Not all of my students are as successful as you."

In linking research results into the realm of education, sometimes many things become priorities. One of the priorities that may be used as a reference to relate this is about teaching materials. In this case, teaching materials are products that are used to assist the learning process. Teaching materials are disused in such a way that the learning process is very possible for students to live, in this case, the teaching materials are focused on higher education levels. Educators or lecturers design teaching materials according to the applicable curriculum. Later this adjustment will have a positive impact on the course of learning. This research will link the research results with the learning process in class XI of high school.

Related to efforts to achieve competence, in the learning process that occurs in class XI high school, there are Core Competencies and Basic Competencies that can use the Disorder novel in learning. The core competence in question is 3.11 , namely analyzing the message of a fiction book that is read. While the Basic Competence in question is 4.11 , namely compiling a review of messages from a fiction book that is read.

\section{CONCLUSION}

Research on the novel Disorder by Akmal Nasery Basral obtained nine data related to the optimistic aspect of Seligman. Three data related to the aspect of permanence, one data about pervasiveness, and two data about personalization. This aspect of optimism does not only appear through the main character, namely Permata Pertiwi, but also through the supporting characters, namely Shmuel, Professor Shochet, Professor Mboi, and Vena.

The results of this study can be used as teaching materials for Indonesian subjects because this novel has a positive side of optimism that can be taught to high school students in class XI. discusses how a person views failure and success due to internal and external factors. From the researcher's point of view, this study 
can still be continued by exploring the expressive, objective, and pragmatic approaches of this literary work. Because this study is a small part that can be peeled off from the Novel Disorder universe that can still be researched in other parts.

\section{ACKNOWLEDGMENT}

We want to thank all respondents for taking part in this study. We also thank the University of Lampung LPPM for funding this research.

\section{REFERENCES}

[1] H. Prasetyo, M. Munaris, and S. Samhati, "Representasi Pdri Dalam Novel Presiden Prawiranegara Dan Pembelajaran Sastra Di Perguruan Tinggi," J-SIMBOL (Bahasa, Sastra, dan Pembelajarannya), vol. 3, no. 2, 2015.

[2] I. Lusiawati, "Membangun Optimisme pada Seseorang Ditinjau dari Sudut Pandang Psikologi Komunikasi," J. TEDC, vol. 10, no. 3, pp. 147-151, 2019.

[3] A. Wicaksono, Pengkajian Prosa Fiksi (edisi revisi). Garudhawaca, 2017.
[4] A. F. Rifki, "Analisis Nilai Pendidikan Moral Dalam Novel Dahlan: Sebuah Novel Karya Haidar Musyafa." IAIN Purwokerto, 2021.

[5] B. Nurgiyantoro, Teori pengkajian fiksi. UGM press, 2018.

[6] H. Prasetyo, "Nilai-Nilai Pendidikan Tasawuf Dalam Buku 99 Untuk Tuhanku Karya Emha Ainun Nadjib Dan Relevansinya Dengan Materi Aqidah Akhlak Kelas Xii Madrasah Aliyah." IAIN Ponorogo, 2020.

[7] N. Febriyanti, "Hubungan Antara Harga Diri Dengan Optimisme Pada Mahasiswa Jurusan Manajemen Universitas Muhammadiyah Palembang." UIN Raden Fatah Palembang, 2020.

[8] A. Rukajat, Pendekatan Penelitian Kualitatif (Qualitative Research Approach). Deepublish, 2018.

[9] S. P. Rukin, Metodologi Penelitian Kualitatif. Yayasan Ahmar Cendekia Indonesia, 2019.

[10] V. D. K. Ompusunggu and N. Sari, "Penggunaan Edmodo Sebagai Media Pembelajaran Matematika," J. CURERE, vol. 3, no. 1, 2019 . 